\title{
Preharvest Fungicide, Potassium Sorbate, or Chitosan Use on Quality and Storage Decay of Table Grapes
}

E. Feliziani, Department of Agricultural, Food, and Environmental Sciences, Marche Polytechnic University, 60131 Ancona, Italy; J. L. Smilanick, D. A. Margosan, and M. F. Mansour, United States Department of Agriculture-Agricultural Research Service (USDA-ARS) San Joaquin Valley Agricultural Sciences Center, Parlier, CA 93648; G. Romanazzi, Department of Agricultural, Food, and Environmental Sciences, Marche Polytechnic University; S. Gu and H. L. Gohil, Department of Viticulture and Enology, California State University, Fresno, CA 93740; and Z. Rubio Ames, USDA-ARS San Joaquin Valley Agricultural Sciences Center, Parlier, CA 93648

\begin{abstract}
Feliziani, E., Smilanick, J. L., Margosan, D. A., Mansour, M. F., Romanazzi, G., Gu, S., Gohil, H. L., and Rubio Ames, Z. 2013. Preharvest fungicide, potassium sorbate, or chitosan use on quality and storage decay of table grapes. Plant Dis. 97:307-314.

Potassium sorbate, a program of four fungicides, or one of three chitosan formulations were applied to clusters of 'Thompson Seedless' grape berries at berry set, pre-bunch closure, veraison, and 2 or 3 weeks before harvest. After storage at $2^{\circ} \mathrm{C}$ for 6 weeks, the natural incidence of postharvest gray mold was reduced by potassium sorbate, the fungicide program, or both together in a tank mixture, in 2009 and 2010. In 2011, the experiment was repeated with three chitosan products (OII-YS, Chito Plant, and Armour-Zen) added. Chitosan or fungicide treatments significantly reduced the natural incidence of postharvest gray mold among grape berries. Berries harvested from vines

treated by two of the chitosan treatments or the fungicide program had fewer infections after inoculation with Botrytis cinerea conidia. None harmed berry quality and all increased endochitinase activity. Chitosan decreased berry hydrogen peroxide content. One of the chitosan formulations increased quercetin, myricetin, and resveratrol content of the berry skin. In another experiment, 'Princess Seedless' grape treated with one of several fungicides before 4 or 6 weeks of cold storage had less decay than the control. Fenhexamid was markedly superior to the other fungicides for control of both the incidence and spread of gray mold during storage.
\end{abstract}

After harvest, grape berries are particularly susceptible to severe losses by gray mold, caused by Botrytis cinerea, because this pathogen grows under cold storage temperatures and spreads rapidly from one berry to others (nesting) by aerial mycelial growth (43). Methods to control postharvest diseases are of interest to both growers who use conventional fungicides and those who chose to avoid their use; for example, to produce grape berries in compliance with "organic" production rules (48). Furthermore, fungicide resistance has been frequently detected in $B$. cinerea populations exposed to fungicides applied to control bunch rot in grape vineyards (16). The use of chitosan, a natural substance, has been considered a valid alternative. Chitosan has been proven to control numerous pre- and postharvest diseases on various horticultural commodities and fruit $(4,36)$ and, among them, to be effective in controlling $B$. cinerea and eliciting plant defense in table grape thought pre- and postharvest applications $(26,34,37,40,47)$. However, the influence of preharvest commercial chitosan treatments on chitinase activity and its nature (endo- or exochitinase activity) on the composition of phenolic compounds or hydrogen peroxide content of grape berries has not been reported. Little is known about the influence of repeated chitosan applications on many aspects of berry quality, such as size, texture, and maturation rate.

Corresponding author: J. L. Smilanick,

E-mail: Joe.Smilanick@ars.usda.gov

Accepted for publication 3 October 2012.

http://dx.doi.org/10.1094/PDIS-12-11-1043-RE

This article is in the public domain and not copyrightable. It may be freely reprinted with customary crediting of the source. The American Phytopathological Society, 2013.
Potassium applications begun after the onset of veraison are known to increase the soluble solids contents of grape berries and increase berry firmness $(21,28,44)$. Potassium sorbate inhibits the growth and sporulation of $B$. cinerea, and many other fungi, in vitro (27). Karabulut and coworkers (19) reported that a single application of potassium sorbate applied to harvested grape berries partially controlled subsequent gray mold during cold storage. Therefore, potassium sorbate could influence both grape quality and postharvest decay, and be a commercially feasible treatment. It has a low order of toxicity to workers and the environment, is inexpensive and readily available, is exempt from residue tolerances (8), and the risk of resistance in the pathogen population is probably low. Unlike chitosan, however, it is not approved for use in "organic" products in the United States (48).

Although there are a number of fungicides approved for use on table grape berries produced under conventional practices, reports about their effectiveness to control postharvest decay are few $(9,42)$. No reports describe the influence of residual fungicide content in the fruit on the incidence and spread of $B$. cinerea among grape berries during storage, and this information would be valuable in the selection and timing of fungicides to use in vineyard fungicide programs.

The aim of our work was to compare the effectiveness of several approaches available to grape growers to control gray mold that could be applied in vineyards, including three chitosan-containing products, potassium sorbate, and a program of four conventional fungicide formulations to control postharvest decay of 'Thompson Seedless' grape berries. The size, texture, and appearance of table grape berries are of particular importance compared with berries grown for wine production or raisins. Therefore, the influence of materials applied in the vineyard on these aspects is of critical practical importance. We also determined their effect on berry size, weight, $\mathrm{pH}$, titratable acidity, soluble solids content, firmness, and 
chitinase activity, and the contents of potassium, phenolic compounds, and hydrogen peroxide.

\section{Materials and Methods}

Vineyard treatments. A single vineyard of 'Thompson Seedless' grapevines, approximately 50 years in age, drip irrigated and located at the San Joaquin Valley Agricultural Sciences Center in Parlier, CA, was used in 2009, 2010, and 2011. Elemental sulfur dust was applied repeatedly to control powdery mildew. There were four treatments in 2009 and 2010 and six treatments in 2011, each repeated in six blocks that corresponded to six rows, each of them separated by a two non-treated rows. Each vineyard plot (a total of 24 in 2009 and 2010 and 36 in 2011) consisted of five vines spaced $1.7 \mathrm{~m}$ apart in rows with $3.5 \mathrm{~m}$ between rows. In all the years, a randomized block design was used, and the treatments were re-randomized each year. Treatments were assigned to plots using a random number generator (Excel; Microsoft Corp.). The vines were not girdled or treated with gibberellic acid to increase berry size. The treatments were applied four times: at berry set, bunch closure, veraison, and 2 weeks before harvest in 2009 and 2010; and at berry set, bunch closure, veraison, and 3 weeks before harvest in 2011. In all years, treatments were applied from a powered sprayer and the clusters were wetted until run-off. All treatments contained surfactant (Latron B1956; BFR Products) at 0.3 $\mathrm{ml}$ liter $^{-1}$. Potassium sorbate (Fruit Growers Supply) was applied at $3.33 \mathrm{~g}$ per vine from a solution containing $0.5 \%$ (wt/vol) potassium sorbate. The fungicide program consisted of an initial application of pyrimethanil (Scala SC at $1.1 \mathrm{ml}$ per vine; Bayer Crop Science) at berry set; cyprodinil + fludioxonil (Switch $62.5 \mathrm{WG}$ at $0.4 \mathrm{~g}$ per vine; Syngenta) at bunch closure; pyraclostrobin + boscalid (Pristine WG at $0.6 \mathrm{~g}$ per vine; BASF) at the onset of veraison; and, finally, fenhexamid (Elevate 50WDG at $0.5 \mathrm{~g}$ per vine; Arysta LifeScience) at two (2009 and 2010) or three (2011) weeks before harvest. These are the approximate common commercial rates at the time these tests were conducted (42). Potassium sorbate alone, the fungicide program, and the fungicide program plus potassium sorbate were applied in 2009 and 2010. The chitosan-containing products, applied in the 2011 tests only, were applied at $1 \%$ chitosan concentration. The treatment of fungicide program plus potassium sorbate was omitted in 2011. Chitosan-A (OII-YS; Venture Innovations), chitosan-B (Chito Plant; ChiPro $\mathrm{GmbH}$ ), and chitosan-C (Armour-Zen; Botry-Zen Limited) were applied at 112 $\mathrm{ml}, 6.7 \mathrm{~g}$, and $45 \mathrm{ml}$, respectively, per vine. Control plots were treated with water.

Natural postharvest decay. In all, $10 \mathrm{~kg}$ (five or six clusters from each vine of the five vines in each plot for a total of 27 grape clusters) from each plot were harvested and placed in plastic bags and placed in expanded polystyrene boxes containing nine bags each. The clusters selected were free of defective or decayed berries. The boxes were stored at $2{ }^{\circ} \mathrm{C}$ under humid conditions $(90$ to $99 \%$ relative humidity [RH]) in darkness for 6 weeks, when the natural incidence of decay and shatter was counted and the rachis appearance was rated. Gray-mold-infected grape berries were identified by the characteristic slip-skin symptom and sporulation. The slip skin condition is a consequence of the growth of $B$. cinerea under the berry skin that causes it to easily separate from the underlying tissues when touched. The incidence of decay by other fungi was also recorded. Percentages were calculated by dividing the number of infected berries by the average total number of berries within each polyethylene bag. The rachis appearance rating employed a scale of 0 to 5 , where $0=$ fresh and green; $1=$ pedicels only are brown; $2=$ all pedicels and less than $50 \%$ of the laterals are brown; 3 = pedicels and more than $50 \%$ of the laterals are brown; 4 = pedicels and laterals brown, main rachis stem green; and $5=$ rachis entirely brown. The experiment was conducted three times with the fungicide program and potassium sorbate $(2009,2010$, and 2011) and once with the chitosancontaining products (2011).

Postharvest decay after inoculation with $B$. cinerea. B. ciner$e a$ isolate 1440 was grown on potato dextrose agar in petri dishes and incubated at $25 \pm 1{ }^{\circ} \mathrm{C}$ and in darkness for 2 weeks. The pathogen was isolated in 1992 from an infected kiwi fruit in California. It was selected because it sporulated readily, was virulent, and was sensitive to the fungicides evaluated in this study. Sterile water containing $0.1 \%$ Triton $\mathrm{X}-100$ (wt/vol) was added to the dishes and conidia were rubbed from the agar surface with a sterile glass rod. This high-density conidial suspension was passed through two layers of cheesecloth and the number of conidia counted using a hemacytometer. The conidial suspension was diluted with sterile water to contain $10^{4}$ conidia $\mathrm{ml}^{-1}$. Three repetitions of 30 berries from each plot were selected from 10 to 20 clusters by clipping the terminal berries from the second lateral branch located from the top of the rachis. The detached berries were placed above a grid, sprayed (Spray Gun; Harbor Freight Tools) to run-off with the conidial suspension, and stored at $15^{\circ} \mathrm{C}$ under humid conditions ( 90 to $99 \% \mathrm{RH}$ ) in darkness. Three weeks after inoculation, the incidence and severity of berry decay were recorded. The incidence was expressed as the percentage of infected berries. The severity was assigned into classes according the berry surface percentage covered by the fungal mycelium. The classes were $0=$ uninfected berry, $1=$ infected and discolored but no surface mycelium present, $2=$ surface mycelium just visible to $25 \%$ of the berry surface, $3=$ 26 to $50 \%$ of the berry surface covered with mycelium, and $4=$ more than $50 \%$ of the berry surface covered with mycelium. The proportion of infected berries per replicate and McKinney Index values, which incorporated both incidence and severity, were calculated as the weighted average of the disease as a percentage of the maximum possible level (25). Berries were collected from the plots three times on consecutive days before the quality harvest, and the experiment repeated with each collection.

Quality characteristics. Berries were selected from clusters by clipping the terminal berries from the second lateral branch located at the top of the rachis. Soluble solids were determined repeatedly at biweekly intervals among the treatments before harvest during 2009, 2010, and 2011. In 2009 and 2010, the soluble solids contents were determined from a 20-berry sample collected from each of the treatment plots and were pooled and macerated before the soluble solids were determined, so the variance in these measurements could not be calculated. In 2011, thorough quality evaluations of the berries were conducted. One hundred berries were collected from clusters by clipping one or two terminal berries from the second lateral branch located at the top of the rachis of mature clusters from each plot. These were weighed to determine the mean weight per berry and their firmness and diameter were measured (FirmTech 2; BioWorks). The berries were blended (Blender 5011; Waring) at high speed for $30 \mathrm{~s}$ and the homogenate was centrifuged for $10 \mathrm{~min}$ at $9,000 \times \mathrm{g}$. The supernatant $\mathrm{pH}(\mathrm{pH}$ Meter 320; Corning), total acidity (TIM850 Titration Manager; Radiometer Analytical), potassium content (C-131 Compact Potassium Ion Meter; Horiba), and soluble solids content (Pocket Refractometer PAL-1; ATAGO) were recorded.

Chitinase activity. Chitinase activity was assessed in berry skin and flesh in preparations by the method of Byrne et al. (5), with some modifications. One hundred berries were collected from clusters by clipping one or two terminal berries from the second lateral branch located at the top of the rachis of mature clusters from each plot. Frozen berries, in which seed traces were manually removed, were blended, and $4 \mathrm{~g}$ of the homogenate was added to

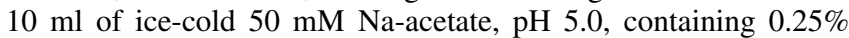
Triton X-100 (wt/vol), then centrifuged at $9,000 \times g$ for $10 \mathrm{~min}$. Chitinase activity in the extract supernatant was determined using three different substrates (Chitinase Assay Kit; Sigma-Aldrich): (i) 4-methylumbelliferyl $\beta$-D-N, $\mathrm{N}^{\prime}, \mathrm{N}^{\prime \prime}$-triacetylchitotriose, which is an endochitinase substrate; (ii) 4-methylumbelliferyl $\mathrm{N}$-acetyl- $\beta$ D-glucosaminide; and (iii) 4-methylumbelliferyl-N,N'-diacetyl- $\beta$ D-chitobiose. The last two are exochitinase substrates. From these substrates, chitinase hydrolysis liberates 4-methylumbelliferone, whose fluorescence was measured using a fluorometer (Spectra$\max$ M2; Molecular Device), with excitation at $360 \mathrm{~nm}$ and emission at $450 \mathrm{~nm}$. One unit of chitinase activity released $1 \mu \mathrm{mol}$ of 
4-methylumbelliferone from the appropriate substrate per minute at $\mathrm{pH} 5.0$ and $37^{\circ} \mathrm{C}$. Chitinase activity was expressed as units per gram of proteins contained in the extract supernatant. Protein content was measured through bicinchoninic acid (BCA Protein Assay Reagent; ThermoFisher Scientific), using bovine serum albumin as standard protein.

Hydrogen peroxide content. Hydrogen peroxide content of the berries was determined with $2^{\prime}, 7^{\prime}$-dichlorodihydrofluorescein diacetate $\left(\mathrm{H}_{2} \mathrm{DCF}-\mathrm{DA}\right.$; Sigma-Aldrich) according to the method of Macarisin and coworkers (24). $\mathrm{H}_{2}$ DCF-DA was dissolved in anhydrous dimethyl sulfoxide (Sigma-Aldrich) to make a $10 \mathrm{mM}$ stock solution, which was frozen $\left(-20^{\circ} \mathrm{C}\right)$ in aliquots and thawed just before the analysis. A sample of 50 berries per treatment, selected from clusters by clipping the terminal berries from the second lateral branch located at the top of the rachis, were frozen in liquid nitrogen after harvest and stored at $-80^{\circ} \mathrm{C}$. The berries were reduced to powder in liquid nitrogen with a mortar and pestle, and $0.5 \mathrm{~g}$ of the powder was placed in a microcentrifuge tube and di-

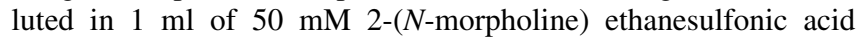
(Sigma-Aldrich) buffer, $\mathrm{pH}$ 6.5. Three replicates per each plot were prepared. The microcentrifuge tubes were vortexed briefly and centrifuged at $18,000 \times g$ for $5 \mathrm{~min}$ at $4^{\circ} \mathrm{C}$. The supernatants were collected and $150 \mu \mathrm{l}$ was pipetted in a 96-well plate containing 150 $\mu \mathrm{l}$ of $0.02 \mathrm{mM} \mathrm{H} \mathrm{H}_{2}$ DCF-DA in each well. $\mathrm{H}_{2} \mathrm{O}_{2}$ content was determined after $24 \mathrm{~h}$ of incubation at room temperature and in darkness by measuring fluorescence intensity (Spectramax M2; Molecular Device), with an excitation wavelength of $485 \mathrm{~nm}$ and an emission wavelength of $530 \mathrm{~nm}$. Hydrogen peroxide content was expressed as a percentage of the hydrogen peroxide content of the control grape berries.

Hydrogen peroxide localization by scanning electron microscope. Grape berries were rapidly frozen by plunging them in liquid nitrogen; then they were stored at $-80^{\circ} \mathrm{C}$ until use. One berry from each treatment was fractured with a chilled scalpel. Pieces that included the berry epidermis with approximate dimensions of 6 by $3 \mathrm{~mm}$ and $2 \mathrm{~mm}$ in thickness were placed in a six-well holder and the holder was then placed sequentially into a container with 5 $\mu \mathrm{M} \mathrm{CeCl}{ }_{3}$ in $0.1 \mathrm{M}$ 1,4-piperazinediethanesulfonic acid buffer (PIPES) (Sigma-Aldrich), 4\% (vol/vol) glutaraldehyde in $0.1 \mathrm{M}$ PIPES buffer, and water purified by reverse osmosis (RO). The grape pieces were processed in a vacuum-capable microwave oven (BioWave Pro 36500; Ted Pella, Inc.) and, while in the six-well holder, they treated using the following protocol: (i) they were placed in the $5 \mu \mathrm{M} \mathrm{CeCl}_{3}$ solution and treated under vacuum for 60 $\mathrm{s}$ at $150 \mathrm{~W}$ and for $60 \mathrm{~s}$ at $0 \mathrm{~W}$; this cycle was repeated four times; (ii) they were placed in the $4 \%$ glutaraldehyde solution for $60 \mathrm{~s}$ at $150 \mathrm{~W}$ and $60 \mathrm{~s}$ at $0 \mathrm{~W}$; this cycle was repeated four times; and (iii) they were placed in RO water for $120 \mathrm{~s}$ at $100 \mathrm{~W}$ and $120 \mathrm{~s}$ at $0 \mathrm{~W}$; this cycle was repeated three times and, after a change of water, it was repeated another three times. The grape pieces were transferred through a dehydration series of $25,50,75,95$, and $100 \%$ ethanol and, finally, a second refreshed $100 \%$ ethanol solution. With each dehydration step, the grape pieces were microwaved for $40 \mathrm{~s}$ at $150 \mathrm{~W}$ and $40 \mathrm{~s}$ at $0 \mathrm{~W}$ and each step of this cycle was repeated twice. The dehydrated berries were transferred to specimen holders and critical point dried (Autosamidri-815B supercritical drier; Tousimis Research Corporation). Dried specimens were mounted on carbon-coated aluminum stubs and examined with a scanning electron microscope (model S-3500N; Hitachi HighTechnology America Corp.). Cerium was detected by an energydispersive $\mathrm{x}$-ray detector (EVEX).

Phenolic compound analysis. Fifty berries were collected from clusters by clipping one or two terminal berries from the second lateral branch located at the top of the rachis of mature clusters from each plot. They were washed with water, frozen at $-20^{\circ} \mathrm{C}$, and peeled by hand, and their skins were placed in ( $1 \mathrm{ml}$ per berry) $70 \%$ acetone and $30 \%$ distilled deionized water containing $0.1 \%$ ascorbate (wt/vol) and agitated on an orbital shaker for $24 \mathrm{~h}$ in darkness at room temperature. Extracts were then filtered through Whatman Number 1 filter paper and evaporated (Multivapor P-12;
Buchi Corporation) at $35^{\circ} \mathrm{C}$ with partial vacuum $(400 \mathrm{~mm} \mathrm{Hg}$ ) to remove the acetone. The evaporated samples were adjusted to 50 $\mathrm{ml}$ with distilled deionized water. Approximately $20 \mathrm{ml}$ of each sample was stored at $-20^{\circ} \mathrm{C}$ in glass vials. To determine the composition of phenolic compounds, an HPLC (Prominence; Shimadzu Corporation) with two pressure pumps and a diode array UV-visible detector (SPD-M10 AVP) coupled and connected to an LC real-time program was used. Samples were thawed and, after adding $1 \mathrm{ml}$ of solvent B to $250 \mu \mathrm{l}$, were centrifuged at 14,000 rpm for $10 \mathrm{~min}$. Supernatants were drawn into auto-sampling vials via a syringe attached to a 13-mm filter (Acrodisc Syringe Filter; Pall Scientific). The samples were loaded into a Novapak RP C18 column, 3.9 by $300 \mathrm{~mm}$ and $4-\mu \mathrm{m}$ particle size (Waters), that was used for the stationary phase. The column was connected to a Novapak guard column with the same material. The flow rate of the mobile phase was $0.5 \mathrm{ml} \mathrm{min}{ }^{-1}$, which separated the individual phenolics. The solvents, concentration gradient used for phenolic compound separation, and preparation of gallic acid, resveratrol, quercetin, catechin, and epicatechin (Sigma Aldrich) standards were the same as described by Lamuela-Raventós and Waterhouse (23). Standard curves were developed by comparing the concentrations of each standard with its peak area. Individual phenolics were identified and calculated by comparing the retention time and the absorption spectrum from 280 to $365 \mathrm{~nm}$ on a chromatogram plot with those of the standards.

Effect of residual fungicide content of berries on postharvest decay. A second experiment was conducted to evaluate the influence of the residual fungicide content deposited on berries on their subsequent postharvest decay. Clusters of mature 'Princess Seedless' table grape berries were placed immediately after harvest on plastic racks and sprayed (Spray Gun; Harbor Freight Tools) to run-off with fungicides at concentrations that approximate those used commercially in vineyards where the maximum fungicide application rates indicated on the U.S. Environmental Protection Agency (EPA)-approved product label in a water volume of 1,900 liter ha $\mathrm{h}^{-1}$ were used (42). They were (i) pyraclostrobin and boscalid at $59 \mu \mathrm{g} \mathrm{liter}^{-1}$ and $116 \mu \mathrm{g} \mathrm{liter}^{-1}$, respectively; (ii) cyprodinil at $270 \mu \mathrm{g}$ liter $^{-1}$ (Vangard; Syngenta); (iii) pyrimethanil at $370 \mu \mathrm{l}$ liter $^{-1}$; and (iv) fenhexamid at $290 \mu \mathrm{g} \operatorname{liter}^{-1}$. After the clusters dried in air (about $2 \mathrm{~h}$ ), a single berry infected just before placement by the injection of $20 \mu \mathrm{l}$ of a suspension containing $B$. cinerea, isolate 1440 , at $10^{6}$ conidia $\mathrm{ml}^{-1}$ was placed in the center of each cluster. Two boxes that contained 10 clusters each were prepared for each fungicide treatment; one was examined after 4 weeks and the other after 6 weeks at $1{ }^{\circ} \mathrm{C}$ under humid conditions ( 90 to $99 \%$ RH) in darkness. Observations included (i) spread of gray mold from a single, untreated berry previously inoculated with $B$. cinerea conidia and placed within the cluster after fungicide treatment (spread was determined by counting the num-

Table 1. Influence of four preharvest applications (at berry set, bunch closure, veraison, and 2 weeks before harvest) of potassium sorbate (PS) alone, a fungicide program (FP) alone, or a combination of both, on the postharvest decay of 'Thompson Seedless' grape berries ${ }^{\mathrm{y}}$

\begin{tabular}{lccccc}
\hline & \multicolumn{4}{c}{ Decay after storage (\%) } \\
\cline { 2 - 3 } Treatments & Gray mold & Other rots $^{\mathbf{2}}$ & & Gray mold & Other rots \\
\cline { 2 - 3 } \cline { 5 - 6 } Control & $15.1 \mathrm{a}$ & $1.9 \mathrm{a}$ & & $24.2 \mathrm{a}$ & $5.0 \mathrm{a}$ \\
PS & $4.9 \mathrm{~b}$ & $1.4 \mathrm{a}$ & & $6.9 \mathrm{~b}$ & $4.2 \mathrm{a}$ \\
FP & $1.1 \mathrm{c}$ & $1.1 \mathrm{a}$ & & $4.7 \mathrm{bc}$ & $4.1 \mathrm{a}$ \\
FP + PS & $1.8 \mathrm{bc}$ & $1.4 \mathrm{a}$ & & $3.7 \mathrm{c}$ & $4.4 \mathrm{a}$ \\
\hline
\end{tabular}

y The FP consisted of applications of pyrimethanil, cyprodinil + fludioxonil, pyraclostrobin + boscalid, or fenhexamid at first, second, third, and final applications, respectively. Clusters were examined after 6 weeks of storage at $2^{\circ} \mathrm{C}$. Values within columns followed by unlike letters are significantly different according to Tukey's honestly significant difference $(P=0.05)$. Statistical analysis employed arcsine transformed values; actual values are shown.

z Alternaria and Penicillium spp. 
ber of new infected berries that were adjacent to the inoculated berry); (ii) natural incidence of gray-mold-infected berries; (iii) incidence of berries infected by other fungi; and (iv) residues of the applied fungicide after 6 weeks. A single sample of 50 healthy berries was collected from each treatment for residue analysis. Fungicides residues were determined by the method of Karaca et al. (20). The experiment was done once.

Statistical analysis. Data were analyzed by a one- or two-way analysis of variance followed by Fisher's protected least significant difference or Tukey's honestly significant difference test at $P=$ 0.05 (SPSS Statistics 17.0 Inc.). In the statistical analysis of the randomized complete block design, the block (row) is considered as a second factor. Percentage data were arcsine transformed before analysis to improve homogeneity of variance when the range of percentages was greater than 40 . Actual values are shown.

\section{Results}

In 2009 and 2010, the natural incidence of postharvest decay among the treatments was mostly caused by $B$. cinerea (Table 1 ). The most effective treatment was the fungicide program, alone or with potassium sorbate, in 2009; whereas, in 2010, the fungicide program and potassium sorbate were similarly effective. The incidence of decay caused by other fungi was low in 2009 (1 to 2\%) and somewhat higher (4 to 5\%) in 2010. In both years, control of other fungi by the treatments was poor. Among all of the treatments, the rate of soluble solids increase was slightly higher than the control treatments among potassium-sorbate-treated grape berries in all years, although not significantly $(F=1.44$; $\mathrm{df}=5 ; P$ $=0.25$ ) so in 2011 , when the variability among the treatments was high. The soluble solids contents on the day of harvest of the control berries in 2009, 2010, and 2011 was 16.6, 16.9, and 18.2 $( \pm 0.9)$, respectively, and among those treated with potassium sorbate it was $17.7,18.1$, and $18.7( \pm 1.0)$, respectively. In 2011 , there were no statistical differences in soluble solids of control berries and those treated with potassium sorbate.

In 2011, the natural incidence of postharvest gray mold was markedly reduced $(F=22.9 ; \mathrm{df}=5 ; P=0.00)$ by the fungicide regime and moderately reduced by the chitosan treatments (Table $2)$. Decay by other pathogens was most reduced ( $F=19.85$; $\mathrm{df}=5$; $P=0.00$ ) by the chitosan-A and the fungicide regime. All of the treatments reduced berry shatter $(F=10.65 ; \mathrm{df}=5 ; P=0.00)$, and some slightly but significantly reduced berry shrivel $(F=4.56 ; \mathrm{df}=$ 5; $P=0.00)$ or improved rachis appearance $(F=4.43$; df $=5 ; P=$ $0.00)$ compared with the control. Berry shrivel or "water berry" disorder $(11,31)$ was present in the vineyard (Table 2). The number of infections and severity of gray mold infections that occurred after artificial inoculation with $B$. cinerea of berries collected from these treatments was reduced by two of the chitosan formulations and the fungicide regime (Fig. 1). Visible and objectionable browncolored deposits were present on the berries where chitosan-C formulation had been applied.

In 2011, vineyard treatments significantly but modestly influenced titratable acidity $(F=4.71 ; \mathrm{df}=5 ; P=0.04)$, firmness $(F=$
44.03; df $=5 ; P=0.00)$, berry weight $(F=3.51 ; \mathrm{df}=5 ; P=0.02)$, and berry diameter $(F=10.91 ; \mathrm{df}=5 ; P=0.00)$, and did not alter soluble solids $(F=1.44 ; \mathrm{df}=5 ; P=0.25)$, juice $\mathrm{pH}(F=1.8 ; \mathrm{df}=$ $5 ; P=0.15)$, and potassium content $(F=1.56 ; \mathrm{df}=5 ; P=0.21)$ significantly (Table 3 ). None of the treatments were significantly different from the control in titratable acid content; the lowest values $\left(5.08 \mathrm{~g}\right.$ tartaric acid liter $\left.^{-1}\right)$ were among the fungicide-treated grape berries and highest (5.68 $\mathrm{g}$ tartaric acid liter $^{-1}$ ) among those treated with potassium sorbate. Firmness was significantly higher than the control after chitosan-C treatment and significantly lower after fungicide, chitosan-A, or chitosan-B treatments. Berry weight was lowest $(1.52 \mathrm{~g})$ after potassium sorbate treatment and highest $(1.75 \mathrm{~g})$ after fungicide treatment. Berry diameter was largest $(14.33 \mathrm{~mm})$ after the fungicide treatments, followed by the chitosan treatments.

All of the treatments increased endochitinase activity $(F=$ 123.0; df $=5 ; P=0.00$ ), with the larger increase caused by chitosan formulation or potassium sorbate (Table 4). Exochitinase activity, as determined using 4-methylumbelliferyl-N, $\mathrm{N}^{\prime}$-diacetyl$\beta$-D-chitobiose as a substrate, was significantly $(F=27.68$; $\mathrm{df}=5$; $P=0.00$ ) increased only on those grape berries previously treated with chitosan-A or chitosan-C, while all of the treatments were similar $(F=6.18$; $\mathrm{df}=5 ; P=0.00)$ to the control for exochitinase

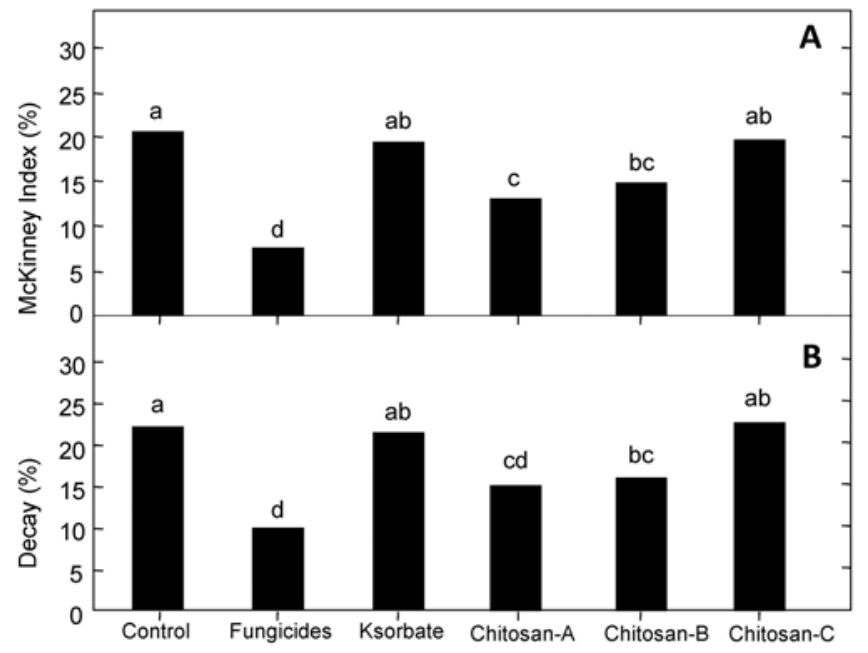

Fig. 1. A, McKinney Index and B, incidence of decay after inoculations with a suspension containing $10^{4}$ Botrytis cinerea conidia ml-1 of 'Thompson Seedless' grape berries that had been treated four times (at berry set, bunch closure, veraison, and 3 weeks before harvest) with water (control), one of three chitosan-containing products (all applied at $1 \%$ chitosan), potassium sorbate (applied at $0.5 \% \mathrm{wt} / \mathrm{vol}$ ), or a fungicide program that consisted of applications of pyrimethanil, cyprodinil + fludioxonil, pyraclostrobin + boscalid, or fenhexamid at the first, second, third, and final applications, respectively. Berries were stored 3 weeks at $15^{\circ} \mathrm{C}$ and 90 to $99 \%$ relative humidity in darkness. Values followed by unlike letters are significantly different according to Tukey's honestly significant difference $(P=0.05)$.

Table 2. Incidence of decay, shatter, shrivel, and rachis appearance of 'Thompson Seedless' table grape berries after 6 weeks of storage at $2^{\circ} \mathrm{C}$ that had been treated four times before harvest (at berry set, bunch closure, veraison, and 3 weeks before harvest) with water (control), one of three chitosan-containing products (all applied at $1 \%$ chitosan), potassium sorbate (applied at $0.5 \% \mathrm{wt} / \mathrm{vol}$ ), or a fungicide program that consisted of applications of pyrimethanil, cyprodinil + fludioxonil, pyraclostrobin + boscalid, or fenhexamid at the first, second, third, and final applications, respectively ${ }^{\mathrm{y}}$

\begin{tabular}{lccccc}
\hline Treatment & Gray mold $(\boldsymbol{\%})$ & ${\text { Other } \boldsymbol{r o t s}^{\mathbf{z}} \boldsymbol{( \% )}}$ & Shatter $(\boldsymbol{\%})$ & Berry shrivel (\%) & Rachis rating \\
\hline Control & $3.9 \mathrm{a}$ & $4.8 \mathrm{a}$ & $11.3 \mathrm{a}$ & $5.6 \mathrm{a}$ & $1.6 \mathrm{a}$ \\
Chitosan-A & $2.1 \mathrm{bc}$ & $1.0 \mathrm{~d}$ & $5.7 \mathrm{~b}$ & $4.9 \mathrm{ab}$ & $1.4 \mathrm{ab}$ \\
Chitosan-B & $2.3 \mathrm{bc}$ & $3.3 \mathrm{bc}$ & $6.8 \mathrm{~b}$ & $3.1 \mathrm{~b}$ & $1.3 \mathrm{ab}$ \\
Chitosan-C & $2.0 \mathrm{c}$ & $3.3 \mathrm{bc}$ & $5.9 \mathrm{~b}$ & $3.6 \mathrm{ab}$ & $1.2 \mathrm{~b}$ \\
Potassium sorbate & $2.8 \mathrm{ab}$ & $4.3 \mathrm{ab}$ & $8.1 \mathrm{~b}$ & $4.8 \mathrm{ab}$ & $1.4 \mathrm{ab}$ \\
Fungicide & $0.7 \mathrm{~d}$ & $2.5 \mathrm{c}$ & $5.3 \mathrm{~b}$ & $3.0 \mathrm{~b}$ & $1.0 \mathrm{~b}$ \\
\hline
\end{tabular}

y Each value is the mean of six replicate 10-kg boxes containing nine grape cluster bags with three clusters each. Decay, shatter, and berry shrivel values are the percentage of affected berries. The rachis rating is a scale of 0 to 5 , where $0=$ fresh and green in appearance to $5=$ rachis entirely brown. Values followed by unlike letters are significantly different according to Tukey's honestly significant difference $(P=0.05)$.

${ }^{\mathrm{z}}$ Alternaria and Penicillium spp. 
activity, as determined using 4-methylumbelliferyl N-acetyl- $\beta$-Dglucosaminide as a substrate.

Vineyard applications of the chitosan-B formulation significantly increased the resveratrol $(F=3.04 ; \mathrm{df}=5 ; P=0.03)$, quercetin $(F=11.05 ; \mathrm{df}=5 ; P=0.00)$, and myricetin $(F=11.46 ; \mathrm{df}=$ $5 ; P=0.00$ ) contents of berry skin (Table 5). The content of quercetin and myricetin after treatments with the other two chitosan formulations was higher but not statistically different from the control. The sole effect of potassium sorbate application was to increase resveratrol content of the berry skin. None of the treatments modified the gallic acid content of the berry skin.

Chitosan-A and chitosan-B formulations significantly $(F=$ 32.34; df $=5 ; P=0.00)$ decreased hydrogen peroxide content of berries, with the greatest reduction of $70 \%$ from chitosan-A (Fig. 2). The location and content of hydrogen peroxide observed in mature Thompson Seedless grape berry tissue was shown by x-ray energy dispersive analysis of cerium hydroxide, a reaction product of hydrogen peroxide and cerium chloride (Fig. 3). The carbon coating did not completely eliminate charging on the specimens; therefore, some distortions were observed. Images indicated relatively high levels of hydrogen peroxide among berries treated with potassium sorbate, the fungicide program, and the control, with lower levels among the grape berries treated with the chitosan formulations.

The residual fungicide content remaining on Princess Seedless grape berries greatly influenced the spread and incidence of gray mold and incidence of other decay pathogens, such as Alternaria and Penicillium spp., during cold storage (Table 6). Fenhexamid was the most effective for the control of gray mold but did not influence the incidence of decay by other fungi. Pyrimethanil and cyprodinil were similar in effectiveness to each other for the control of gray mold, whereas pyraclostrobin + boscalid did not significantly reduce gray mold but did reduce the incidence of decay by other fungi. The U.S. EPA maximum residual fungicide content of fenhexamid, pyrimethanil, cyprodinil, pyraclostrobin, and boscalid in berries is $4,5,2,2$, and $3.5 \mathrm{mg} \mathrm{kg}^{-1}$, respectively (http://www.epa.gov/opp00001/food/viewtols.htm). Only the content of cyprodinil exceeded the tolerance in our work.

\section{Discussion}

Potassium sorbate reduced natural gray mold incidence in two of three study years, demonstrating that repeated applications are effective, as has been shown for postharvest applications (19). The inefficacy of potassium sorbate in the third year of the study may have several possible explanations. The detached berries from these same vines became infected when inoculated with $B$. cinerea conidia, perhaps because the residual potassium sorbate content in grape berries was low. Investigation of the potassium sorbate content and persistence in the berries would help interpret how vineyard sorbate applications controlled gray mold. It declines rapidly in fresh citrus fruit (30). However, potassium sorbate may control gray mold by other than its antimicrobial properties. The modest increases in endochitinase activity and resveratrol content we ob- served in 2011 indicate that induction of resistance by potassium sorbate could have had some role. It is conceivable that potassium sorbate induced significant resistance to infection in 2009 and 2010 but not in 2011 .

In 2011, a high prevalence of "water berry" caused variability in maturity among the grape berries. This disorder causes phloem death in the rachis followed by cessation of sugar and water accumulation in berries $(11,31)$. Although we avoided visibly shriveled and symptomatic berries when sampling, some were probably included, and their lower soluble solids content and softer texture

Table 4. Chitinase activity ( $\mathrm{U} \mathrm{g}^{-1}$ of protein) at harvest of 'Thompson Seedless' grape berries that had been treated four times (at berry set, bunch closure, veraison, and 3 weeks before harvest) with water (control), one of three chitosan-containing products (all applied at $1 \%$ chitosan), potassium (K) sorbate (applied at $0.5 \% \mathrm{wt} / \mathrm{vol}$ ), or a fungicide program that consisted of applications of pyrimethanil, cyprodinil + fludioxonil, pyraclostrobin + boscalid, or fenhexamid at the first, second, third, and final applications, respectively ${ }^{\mathrm{w}}$

\begin{tabular}{lccc}
\hline Treatment & Endochitinase $^{\mathbf{x}}$ & Exochitinase $^{\mathbf{y}}$ & Exochitinase $^{\mathbf{z}}$ \\
\hline Control & $13.7 \mathrm{e}$ & $36.2 \mathrm{ab}$ & $4.7 \mathrm{~b}$ \\
Chitosan-A & $16.9 \mathrm{~b}$ & $39.7 \mathrm{a}$ & $5.3 \mathrm{a}$ \\
Chitosan-B & $15.6 \mathrm{c}$ & $33.2 \mathrm{~b}$ & $4.6 \mathrm{bc}$ \\
Chitosan-C & $17.1 \mathrm{~b}$ & $38.8 \mathrm{a}$ & $5.1 \mathrm{a}$ \\
Fungicide & $14.8 \mathrm{~d}$ & $35.8 \mathrm{ab}$ & $4.5 \mathrm{bc}$ \\
K sorbate & $18.5 \mathrm{a}$ & $39.7 \mathrm{a}$ & $4.4 \mathrm{c}$ \\
\hline
\end{tabular}

wValues followed by unlike letters are significantly different by Fisher's protected least significant difference $(P=0.05)$.

${ }^{\mathrm{x}}$ Endochitinase activity determined using 4-methylumbelliferyl $\beta$-D$\mathrm{N}, \mathrm{N}^{\prime}, \mathrm{N}^{\prime \prime}$-triacetylchitotriose.

y Exochitinase activity determined using 4-methylumbelliferyl N-acetyl- $\beta$ D-glucosaminide.

${ }^{\mathrm{z}}$ Exochitinase activity determined using 4-methylumbelliferyl-N,N'diacetyl- $\beta$-D-chitobiose.

Table 5. Gallic acid, quercetin, myricetin, and resveratrol contents at harvest of 'Thompson Seedless' grape berries that had been treated four times (at berry set, bunch closure, veraison, and 3 weeks before harvest) with water (control), one of three chitosan-containing products (all applied at $1 \%$ chitosan), potassium $(\mathrm{K})$ sorbate (applied at $0.5 \% \mathrm{wt} / \mathrm{vol}$ ), or a fungicide program that consisted of applications of pyrimethanil, cyprodinil + fludioxonil, pyraclostrobin + boscalid, or fenhexamid at the first, second, third, and final applications, respectively ${ }^{\mathrm{z}}$

\begin{tabular}{lcccc}
\hline & \multicolumn{3}{c}{ Contents (mg kg-1 berry weight) } \\
\cline { 2 - 5 } Treatment & Gallic acid & Quercetin & Myricetin & Resveratrol \\
\hline Control & 6.5 & $17.1 \mathrm{bc}$ & $1.8 \mathrm{~b}$ & $0.36 \mathrm{c}$ \\
Chitosan-A & 6.9 & $19.2 \mathrm{~b}$ & $2.0 \mathrm{~b}$ & $0.37 \mathrm{bc}$ \\
Chitosan-B & 7.2 & $23.7 \mathrm{a}$ & $2.9 \mathrm{a}$ & $0.41 \mathrm{ab}$ \\
Chitosan-C & 6.5 & $17.8 \mathrm{bc}$ & $2.1 \mathrm{~b}$ & $0.35 \mathrm{c}$ \\
Fungicide & 6.3 & $14.4 \mathrm{c}$ & $1.8 \mathrm{~b}$ & $0.34 \mathrm{c}$ \\
K sorbate & 7.0 & $14.5 \mathrm{c}$ & $1.8 \mathrm{~b}$ & $0.42 \mathrm{a}$ \\
\hline
\end{tabular}

${ }^{\mathrm{z}}$ Values followed by unlike letters are significantly different by Fisher's protected least significant difference $(P=0.05)$.

Table 3. Characteristics of 'Thompson Seedless' grape berries at harvest that had been treated four times (at berry set, bunch closure, veraison, and 3 weeks before harvest) with water (control), one of three chitosan-containing products (all applied at $1 \%$ chitosan), potassium sorbate (applied at $0.5 \% \mathrm{wt} / \mathrm{vol}$ ), or a fungicide program that consisted of applications of pyrimethanil, cyprodinil + fludioxonil, pyraclostrobin + boscalid, or fenhexamid at the first, second, third, and final applications, respectively ${ }^{\mathrm{z}}$

\begin{tabular}{|c|c|c|c|c|c|c|c|}
\hline Treatment & $\begin{array}{l}\text { Soluble solids } \\
\text { (\% Brix) }\end{array}$ & $\begin{array}{c}\text { Titratable acidity } \\
\left(\text { tartaric acid, } \text { g liter }^{-1}\right)\end{array}$ & $\begin{array}{l}\text { Firmness } \\
(\mathbf{N})\end{array}$ & $\begin{array}{l}\text { Berry weight } \\
\text { (g) }\end{array}$ & $\begin{array}{l}\text { Berry diameter } \\
(\mathbf{m m})\end{array}$ & pH & $\begin{array}{c}\text { Potassium } \\
\text { content (ppm) }\end{array}$ \\
\hline Control & 18.2 & $5.28 \mathrm{abc}$ & $2.64 \mathrm{~b}$ & $1.71 \mathrm{ab}$ & $13.93 \mathrm{c}$ & 3.4 & 1,026 \\
\hline Chitosan-A & 17.8 & $5.36 \mathrm{abc}$ & $2.47 \mathrm{~d}$ & $1.59 \mathrm{ab}$ & $14.08 \mathrm{bc}$ & 3.4 & 1,013 \\
\hline Chitosan-B & 18.0 & $5.57 \mathrm{ab}$ & $2.59 \mathrm{c}$ & $1.58 \mathrm{ab}$ & $14.19 a b$ & 3.3 & 996 \\
\hline Chitosan-C & 19.5 & $5.19 \mathrm{bc}$ & $2.82 \mathrm{a}$ & $1.65 \mathrm{ab}$ & $14.20 \mathrm{ab}$ & 3.4 & 1,016 \\
\hline Potassium sorbate & 18.8 & $5.68 \mathrm{a}$ & $2.70 \mathrm{~b}$ & $1.52 \mathrm{~b}$ & $13.91 \mathrm{c}$ & 3.4 & 1,033 \\
\hline Fungicide & 18.5 & $5.08 \mathrm{c}$ & $2.50 \mathrm{~cd}$ & $1.75 \mathrm{a}$ & $14.33 \mathrm{a}$ & 3.4 & 1,050 \\
\hline
\end{tabular}

${ }^{z}$ Value of firmness, weight, and diameter were the mean of six replicates of 100 berries each. Soluble solids, acidity, $\mathrm{pH}$, and potassium content were the means of six replicates of a filtered macerate prepared from 100 berries per replicate. Values followed by unlike letters are significantly different according to Tukey's honestly significant difference $(P=0.05)$. 
contributed variation in berry quality measurements and made differences among treatments more difficult to resolve.

Foliar applications of potassium sorbate (28) or other sources of potassium $(21,28,44)$ to grape berries were reported to accelerate accumulation of soluble solids in berries, reduce berry size, and increase titratable acidity. The modest increase in resveratrol content of the berry skin we observed is somewhat paradoxical because an increase in soluble solids content, an indication of maturity, was observed after potassium sorbate applications in prior work (28), and advanced maturity is negatively correlated with the capacity for resveratrol synthesis $(3,17)$. However, sorbate also reduced berry size and increased titratable acidity, both characteristic of less mature berries, which is associated with increased resveratrol content $(3,17)$. It is conceivable that the reduction in berry size alone could influence the concentration of the sugars and other components within the berries.

Preharvest fungicide regimes in this and prior reports were shown to significantly reduce subsequent postharvest decay $(9,42)$. Potassium sorbate could be used alone or in a mixture with conventional fungicides to provide partial control of postharvest decay. As a component in a conventional fungicide program, it may retard the development of fungicide-resistant populations of $B$. cinerea in vineyards. Of the conventional fungicides we evaluated, the residual fungicide content that remained after fenhexamid application was markedly superior for the control of both the natural incidence of gray mold and spread of the aerial mycelium of $B$. cinerea among stored grape berries. The residual fungicide content within the berries was below regulatory tolerances (7). Applied after rainfall or immediately before harvest, fenhexamid would be a good choice for use in San Joaquin Valley vineyards, although resistance to this fungicide develops rapidly among $B$. cinerea populations $(9,42)$. During the hot, dry periods of the growing season, summer bunch rot is prevalent in this area, whereas gray mold is not. Summer bunch rot, caused by a complex of fungi and bacteria, is not controlled by fenhexamid, which is primarily a botricide, whereas it can be partially controlled by other fungicides (46) and cultural practices that open the vineyard canopy, such as leaf removal (41).

This is one of few studies where commercial chitosan formulations were evaluated and compared with fungicides in effectiveness in a regime that closely simulated commercial vineyard practices. Relatively non-toxic and environmentally benign, risk of the development of resistance to them in the pathogen population is low. Treatment with chitosan-C caused visible and objectionable
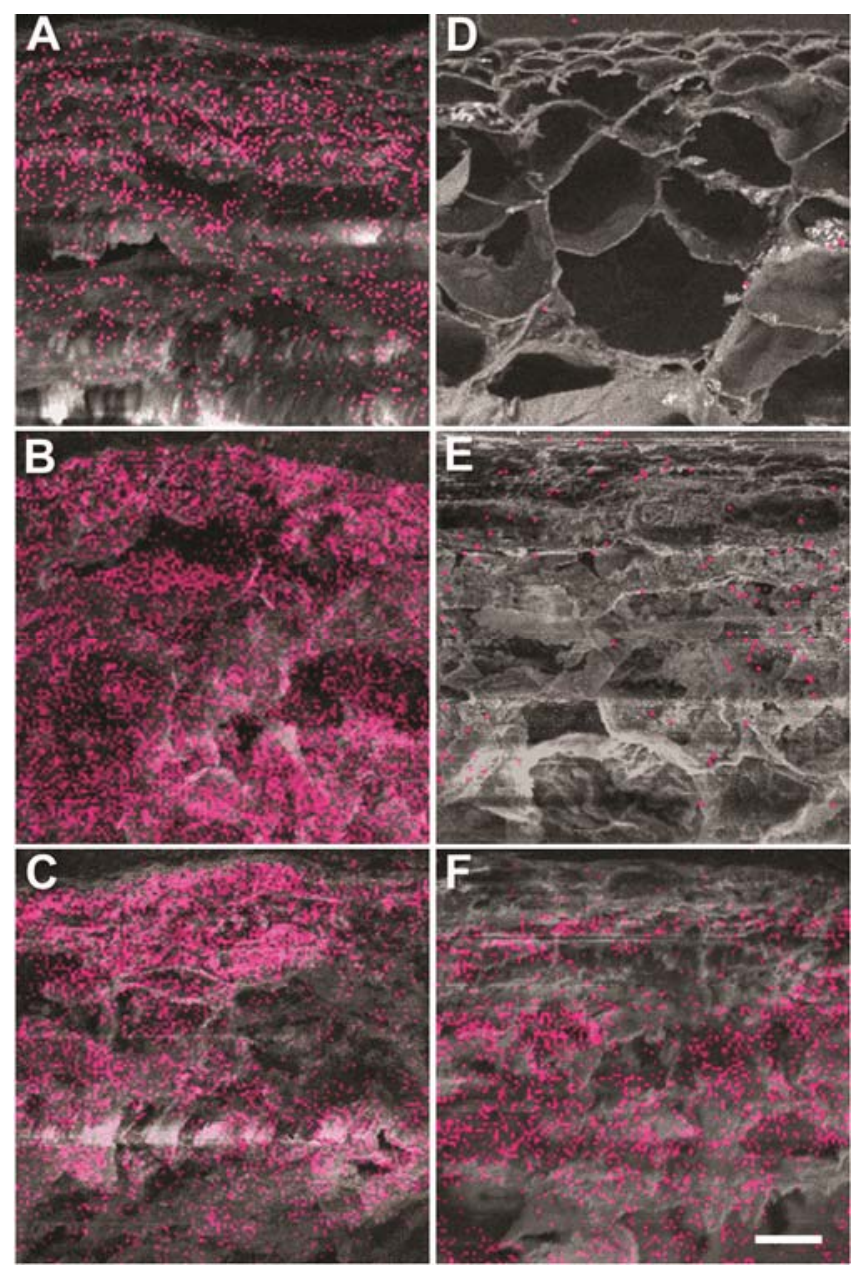

Fig. 3. Location and content of hydrogen peroxide in mature 'Thompson Seedless' grape berry tissue as shown by $x$-ray energy dispersive analysis of cerium hydroxide (pink pixels), a reaction product of hydrogen peroxide and cerium chloride. The epidermis appears at the uppermost portion of each panel with approximately 10 cell layers shown. Berries were treated four times (at berry set, bunch closure, veraison, and 3 weeks before harvest) with $\mathbf{A}$, water; $\mathbf{B}$, potassium sorbate; C, a fungicide program; D, chitosan-A formulation; $E$, chitosan-B formulation; or $\mathrm{F}$, chitosan-C formulation. Bar $=100 \mu \mathrm{m}$.

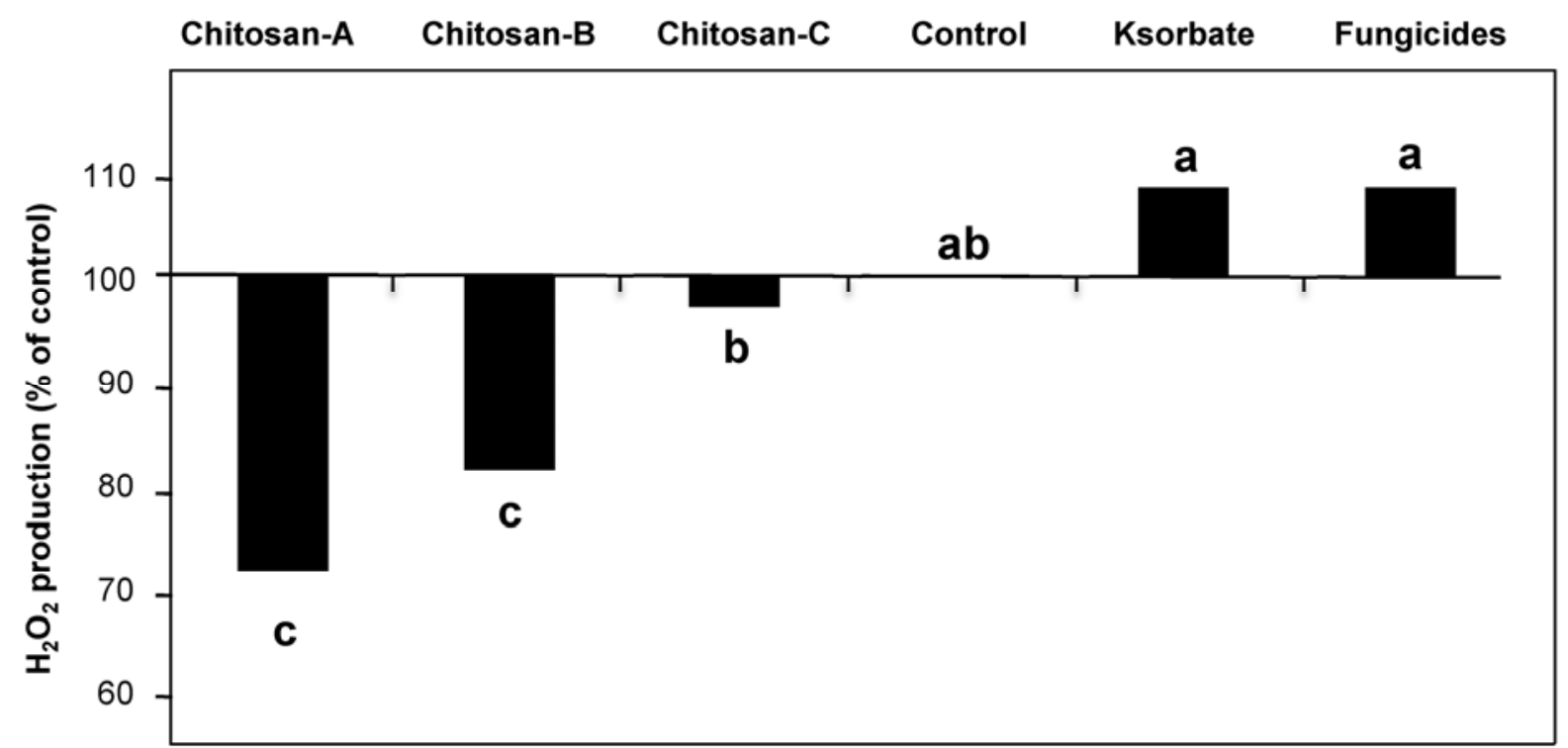

Fig. 2. Relative hydrogen peroxide content immediately at harvest of 'Thompson Seedless' grape berries that had been treated four times (at berry set, bunch closure, veraison, and 3 weeks before harvest) with water (control), one of three chitosan-containing products (all applied at $1 \%$ chitosan), potassium sorbate (applied at $0.5 \%$ wt/vol), or a fungicide program that consisted of applications of pyrimethanil, cyprodinil + fludioxonil, pyraclostrobin + boscalid, or fenhexamid at the first, second, third, and final applications, respectively. Values followed by unlike letters are significantly different according to Tukey's honestly significant difference $(P=0.05)$. 
Table 6. Effect of postharvest treatments with fenhexamid (FENH), pyrimethanil (PYRI), cyprodinil (CYPR), or pyraclostrobin + boscalid (PYRA+BOSC) on the spread of gray mold from a single infected berry placed within 'Princess Seedless' grape clusters after fungicide treatment and on the natural incidence of berries infected by gray mold or other fungi ${ }^{x}$

\begin{tabular}{|c|c|c|c|c|c|c|c|}
\hline \multirow[b]{2}{*}{ Treatments } & \multicolumn{2}{|c|}{$\begin{array}{c}\text { Gray mold spread from infected } \\
\text { berry }\end{array}$} & \multicolumn{2}{|c|}{ Natural gray mold $(\%)$} & \multicolumn{2}{|c|}{ Natural other rots $(\%)^{y}$} & \multirow[b]{2}{*}{ Fungicide $\left(\mathrm{mg} \mathrm{kg}^{-1}\right)^{z}$} \\
\hline & 4 weeks & 6 weeks & 4 weeks & 6 weeks & 4 weeks & 6 weeks & \\
\hline Control & $10.3 \mathrm{a}$ & $23.0 \mathrm{a}$ & $1.4 \mathrm{ab}$ & $4.4 \mathrm{a}$ & 5.6 & $9.7 \mathrm{a}$ & \\
\hline FENH & $0.1 \mathrm{c}$ & $0.9 \mathrm{c}$ & $0.7 \mathrm{c}$ & $0.8 \mathrm{c}$ & 3.7 & $10.3 \mathrm{a}$ & 2.1 \\
\hline PYRI & $2.1 \mathrm{~b}$ & $5.0 \mathrm{~b}$ & $1.1 \mathrm{~b}$ & $1.1 \mathrm{~b}$ & 5.3 & $8.6 \mathrm{ab}$ & 3.8 \\
\hline CYPR & $5.0 \mathrm{~b}$ & $8.9 \mathrm{~b}$ & $1.6 \mathrm{~b}$ & $1.4 \mathrm{~b}$ & 3.7 & $5.7 \mathrm{~b}$ & 4.2 \\
\hline PYRA + BOSC & $9.3 \mathrm{a}$ & $22.8 \mathrm{a}$ & $2.6 \mathrm{a}$ & $4.0 \mathrm{a}$ & 3.1 & $4.2 \mathrm{~b}$ & $1.5+1.5$ \\
\hline
\end{tabular}

${ }^{x}$ Decay incidence was evaluated after 4 and 6 weeks of storage at $1{ }^{\circ} \mathrm{C}$. The residual fungicide contents of the berries of the applied fungicide after 6 weeks of storage were determined. Values within columns followed by unlike letters are significantly different by Fisher's protected least significant difference $(P=0.05)$.

${ }^{\mathrm{y}}$ Alternaria and Penicillium spp.

${ }^{\mathrm{z}}$ Fungicide content.

brown-colored deposits on berries while the other formulations did not. Among the three chitosan formulations, control of natural postharvest gray mold was similar but chitosan-A most effectively controlled natural decay by pathogens other than $B$. cinerea (mainly Alternaria and Penicillium spp.) and the chitosan-C formulation did not retard the spread of $B$. cinerea after inoculation. Because the three formulations were all applied with a chitosan content of $1 \%$, differences in effectiveness could be ascribed to the chemical characteristics of chitosan or to the other components in the formulations. Chitosan forms films on products (38), and the characteristics of the films created by the chitosan formulations we used merit study, particularly because they could constitute a physical barrier to inhibit $B$. cinerea infections. Cuticle and cell thickness in the skin are natural barriers associated with resistance in grape berries to $B$. cinerea $(6,29)$.

The chitosan formulations increased chitinase activity. This enzyme is a pathogenesis-related protein with antimicrobial activity that participates in defense against pathogens (49). Previous work indicated that, in addition to antimicrobial activity $(32,33)$, chitosan induced a series of defensive reactions in grape against $B$. cinerea. Phenylalanine ammonia-lyase (PAL), a key enzyme involved in the synthesis of phytoalexins and phenolic compounds with antifungal activity, was induced by chitosan in both grape leaves $(34,47)$ and berries $(26,40)$. In our work, preharvest, all chitosan treatments induced activity of endochitinase, and chitosan-A and chitosan- $\mathrm{C}$ formulations induced exochitinase (from one of the substrates). This result corroborates findings by TrotelAziz et al. (47) that chitosan applications induced chitinase activity in detached grape leaves.

Chitosan treatments reduced hydrogen peroxide content, which confirms work by Romanazzi et al. (39). It may have been a direct effect, because chitosan itself has antioxidant activity and scavenges hydroxyl radicals $(50,51)$, or an indirect effect, because chitosan was reported to increase peroxidase activity in table grape berries $(26,34)$, which would reduce their hydrogen peroxide content. Peroxidase participates in various physiological processes, such as lignification, suberization, wound healing, and defense mechanisms against pathogen infection (12). The presence of other antioxidants, such as phenols, could have reduced the content of hydrogen peroxide as well because the hydroxyl group and unsaturated double bonds of phenols make them very susceptible to oxidation $(13,35,52)$.

The accumulation of phytoalexin trans-resveratrol and other phenols is considered the primary inducible response of grapevine against a number of biotic and abiotic stresses $(18,22)$. We found that preharvest treatments with the chitosan-B formulation induced the production of phenolic compounds such as resveratrol, which is a stilbene, and myricetin and quercetin, which are flavonols. The other two chitosan formulations showed a trend to increase all of these phenolic compounds except resveratrol but these were not significantly higher than the control. In previous work, preharvest chitosan application enhanced the total phenolic compounds in table grape berries (26) and induction of resveratrol and derivatives was observed following treatment of grapevine leaves with chitosan alone or in combination with copper sulfate (2). Our result corroborates the findings of Iriti et al. (15), in which weekly vineyard chitosan applications increased total polyphenols in grape berries. Furthermore, the induction of phenolic compounds by chitosan is consistent with their induction of PAL activity, a key enzyme in phenol synthesis $(26,34,40,47)$. Moreover, in addition to resveratrol, myricetin and quercetin were also reported to be involved in grape defense against pathogens such as $B$. cinerea $(1,10,14)$ and Erysiphe necator (45). Taware et al. (45) showed myricetin and quercetin increased in grapevine leaves and berries of grape after E. necator infection compared with the asymptomatic organs. Iriti et al. (14) reported that benzothiadiazole improved resistance to infection by $B$. cinerea and enhanced transresveratrol content in 'Merlot' berries from 0.4 to $0.5 \mathrm{mg} / \mathrm{kg}$ and cis-resveratrol from 0.1 to $0.2 \mathrm{mg} / \mathrm{kg}$. In our work, the concentration of resveratrol in berry skins was similar and may have been sufficient to inhibit $B$. cinerea infections.

\section{Acknowledgments}

We thank the California Table Grape Commission and BARD Project Number IS-4476-11 for financial support; R. Borden and L. Marais for the donation of OII-YS and Armour-Zen; and F. Mlikota Gabler, G. Verduzco, K. Fjeld, L. Cerioni, B. McCarthy, and P. Sahota for technical assistance.

\section{Literature Cited}

1. Adrian, M., Jeandet, P., Veneau, J., Waston, L. A., and Bessis, R. 1997. Biological activity of resveratrol, a stilbenic compound from grapevines, against Botrytis cinerea, the causal agent for gray mold. J. Chem. Ecol. 7:1689-1702.

2. Aziz, A., Trotel-Aziz, P., Dhuicq, L., Jeandet, P., Couderchet, M., and Vernet, G. 2006. Chitosan oligomers and copper sulfate induce grapevine defences reactions and resistance to gray mold and downy mildew. Phytopathology 96:1188-1194.

3. Bais, A. J., Murphy, P. J., and Dry, I. B. 2000. The molecular regulation of stilbene phytoalexin biosynthesis in Vitis vinifera during grape berry development. Aust. J. Plant Physiol. 27:425-433.

4. Bautista-Baños, S., Hernández-Lauzardoa, A. N., Velázquez-del Valle, M. G., Hernández-López, M., Ait Barka, E., Bosquez-Molina, E., and Wilson, C. L. 2006. Chitosan as a potential natural compound to control pre and postharvest diseases of horticultural commodities. Crop Prot. 25:108-118.

5. Byrne, N. D., Duxbury, M., and Sharpe, N. 2001. The determination of chitinase activity of grapes: an introductory enzyme assay. Biochem. Mol. Biol. Educ. 29:144-146.

6. Deytieux-Belleau, C., Geny, L., Roudet, J., Mayet, V., Donèche, B., and Fermaud, M. 2009. Grape berry skin features related to ontogenic resistance to Botrytis cinerea. Eur. J. Plant Pathol. 125:551-563.

7. EPA. 2006. Fenhexamid; pesticide tolerance. Fed. Regist. 71:15612-15617.

8. EPA. 2011. $\$ 152.25$ Exemptions for pesticides of a character not requiring FIFRA regulation. Code Fed. Reg. 40:11-13.

9. Franck, J., Latorre, B. A., Torres, R., and Zoffoli, J. P. 2005. The effect of preharvest fungicide and postharvest sulfur dioxide use on postharvest decay of table grapes caused by Penicillium expansum. Postharvest Biol. Technol. 37:20-30.

10. Goetz, G., Fkyerat, A., Metais, N., Kunz, M., Tabacchi, R., Pezet, P., and Pont, V. 1999. Resistance factors to gray mold in grape berries: identification of some phenolics inhibitors of Botrytis cinerea stilbene oxidase. 
Phytochemistry 52:759-767.

11. Hall, G. E., Bondada, B. R., and Keller, M. 2011. Loss of rachis cell viability is associated with ripening disorders in grapes. J. Exp. Bot. 62:1145-1153.

12. Hiraga, S., Sasaki, K., Ito, H., Ohashi, Y., and Matsui, H. 2001. A large family of class III plant peroxidases. Plant Cell Physiol. 42:462-468.

13. Iacopini, P., Baldi, M., Storchi, P., and Sebastiani, L. 2008. Catechin, epicatechin, quercetin, rutin and resveratrol in red grape: content, in vitro antioxidant activity and interactions. J. Food Compos. Anal. 21:589-598.

14. Iriti, M., Rossoni, M., Borgo, M., and Faoro, F. 2004. Benzothiadiazole enhances resveratrol and anthocyanin biosynthesis in grapevine, meanwhile improving resistance to Botrytis cinerea. J. Agric. Food Chem. 52:44064413.

15. Iriti, M., Vitalini, S., Di Tommaso, G., D’Amico, S., Borgo, M., and Faoro, F. 2011. New chitosan formulation prevents powdery mildew infection and improves polyphenols content and free radical scavenging activity of grape and wine. Aust. J. Grape Wine Res. 17:263-269.

16. Jacometti, M. A., Wratten, S. D., and Walter, M. 2010. Review: alternatives to synthetic fungicides for Botrytis cinerea management in vineyards. Aust. J. Grape Wine Res. 16:154-172.

17. Jeandet, P., Bessis, R., and Gautheron, B. 1991. The production of resveratrol $\left(3,5,4^{\prime}\right.$-trihydroxystilbene) by grape berries in different developmental stages. Am. J. Enol. Vitic. 1:41-46.

18. Jeandet, P., Douillet-Breuil, A. C., Bessis, R., Debord, S., Spaghi, M., and Adrian, M. 2002. Phytoalexins from the Vitaceae: biosynthesis, phytoalexin gene expression in transgenic plants, antifungal activity, and metabolism. J. Agric. Food Chem. 50:2731-2741.

19. Karabulut, O. A., Romanazzi, G., Smilanick, J. L., and Lichter, A. 2005. Postharvest ethanol and potassium sorbate treatments of table grapes to control gray mold. Postharvest Biol. Technol. 37:129-134.

20. Karaca, H., Walse, S. S., and Smilanick, J. L. 2011. Effect of continuous 0.3 $\mu \mathrm{L} / \mathrm{L}$ gaseous ozone exposure on fungicide residues on table grape berries. Postharvest Biol. Technol. 62:85-88.

21. Kelany, A. E., Abdel-Wahab, S. M., Abdel-Hafeez, A. A., and Eman, I. A. 2011. Effect of pre-harvest treatments on cluster quality of "Flame Seedless" table grapes cultivar during cold storage. J. Hortic. Sci. Ornam. Plants 3:11-21.

22. Kretschmer, M., Kassemeyer, H.-H., and Hahn, M. 2007. Age-dependent gray mould susceptibility and tissue-specific defence gene activation of grapevine berry skins after infection by Botrytis cinerea. J. Phytopathol. 155:258-263.

23. Lamuela-Raventós, R. M., and Waterhouse, A. L. 1994. A direct HPLC separation of wine phenolics. Am. J. Enol. Vitic. 1:1-5.

24. Macarisin, D., Cohen, L., Eick, A., Rafael, G., Belausov, E., Wisniewski, M., and Droby, S. 2007. Penicillium digitatum suppresses production of hydrogen peroxide in host tissue during infection of citrus fruit. Phytopathology 97:1491-1500.

25. McKinney, H. H. 1923. Influence of soil temperature and moisture on infection of wheat seedlings by Helmintosporium sativum. J. Agric. Res. 26:195218 .

26. Meng, X., Li, B., Liu, J., and Tian, S. 2008. Physiological responses and quality attributes of table grape fruit to chitosan preharvest spray and postharvest coating during storage. Food Chem. 106:501-508.

27. Mills, A. A. S., Platt, H. W., and Hurta, R. A. R. 2004. Effect of salt compounds on mycelial growth, sporulation and spore germination of various potato pathogens. Postharvest Biol. Technol. 34:341-350.

28. Mlikota Gabler, F., Margosan, D. A., Smilanick, J. L., and Hashim-Buckey, J. 2010. Influence of cluster-directed applications of potassium before harvest on the quality of table grapes. Pages 1-4 in: Pro. 6th Int. Table Grape Symp., Davis, CA.

29. Mlikota Gabler, F., Smilanick, J. L., Mansour, M., Ramming, D., and Mackey, B. E. 2003. Correlations of morphological, anatomical, and chemical features of grape berries with resistance to Botrytis cinerea. Phytopathology 93:1263-1273.

30. Montesinos-Herrero, C., Smilanick, J. L, Hurley, J. M., and Palou, L. 2009. Potassium sorbate residue levels and persistence in citrus fruit as detected by a simple colorimetric method. J. Agric. Food. Chem. 57:3458-3463.

31. Morrison, J. C., and Iodi, M. 1990. The influence of waterberry on the development and composition of Thompson Seedless grapes. Am. J. Enol Vitic. 41:301-305

32. Muñoz, Z., and Moret, A. 2010. Sensitivity of Botrytis cinerea to chitosan and acibenzolar-S-methyl. Pest Manage. Sci. 66:974-979.

33. Rabea, E. I., Badawy, M. E. T., Stevens, C. V., Smagghe, G., and Steurbaut, W. 2003. Chitosan as antimicrobial agent: application and mode of action. Biomacromolecules 4:1457-1465.

34. Reglinski, T., Elmer, P. A. G., Taylor, J. T., Wood, P. N., and Hoyte, S. M. 2010. Inhibition of Botrytis cinerea growth and suppression of botrytis bunch rot in grapes using chitosan. Plant Pathol. 59:882-890.

35. Rice-Evans, C. A., Miller, N. J., and Paganga, G. 1997. Antioxidant properties of phenols. Trends Plant Sci. 2:152-159.

36. Romanazzi, G. 2010. Chitosan treatment for the control of postharvest decay of table grapes, strawberry and sweet cherries. Fresh Prod. 4:111115.

37. Romanazzi, G., Lichter, A., Mlikota Gabler, F., and Smilanick, J. L. 2012 Recent advances on the use of natural and safe alternatives to conventional methods to control postharvest gray mold of table grapes. Postharvest Biol. Technol. 63:141-147.

38. Romanazzi, G., Mlikota Gabler, F., Margosan, D., Mackey, B. E., and Smilanick, J. L. 2009. Effect of chitosan dissolved in different acids on its ability to control postharvest gray mold of table grape. Phytopathology 99:1028-1036.

39. Romanazzi, G., Mlikota Gabler, F., Santini, M., Landi, L., Karabulut, O. A., and Smilanick, J. L. 2007. Advances in the use of chitosan to control postharvest decay of table grapes. Pages 327-334 in: Proc. COST 924 Novel Approaches for the Control of Postharvest Diseases and Disorders, Bologna, Italy.

40. Romanazzi, G., Nigro, F., Ippolito, A., Di Venere, D., and Salerno, M. 2002. Effect of pre- and postharvest chitosan treatments to control storage gray mold of table grapes. J. Food Sci. 67:1862-1867.

41. Schilder, A. M. C., Gillett, J. M., and Sysak, R. W. 2010. Evaluation of fungicide programs for control of bunch rots in 'Vignoles' grapes, 2009. Plant Dis. Manage. Rep. 5:SMF057:1-4.

42. Smilanick, J. L., Mansour, M. F., Mlikota Gabler, F., Margosan, D. A., and Hashim-Buckey, J. 2010. Control of postharvest gray mold of table grapes in the San Joaquin Valley of California by fungicides applied during the growing season. Plant Dis. 94:250-257.

43. Snowdon, A. L. 1990. A Color Atlas of Post-Harvest Diseases and Disorders of Fruits and Vegetables. CRC Press, Boca Raton, FL.

44. Strydum, G. J., and Loubser, J. T. 2008. The effect of metalosate calcium and metalosate potassium on sugar accumulation in 'Waltham Cross' (table grapes). Pages 141-156 in: 2008 Albion Conf. Plant Nutr., Midway, UT.

45. Taware, P. B., Dhumal, K. N., Oulkar, D. P., Patil, S. H., and Baneriee, K 2010. Phenolic alteration in grape leaves, berries and wine due to foliar and cluster powdery mildew infections. Int. J. Pharm. Biol. Sci. 1:1-14.

46. Tjamos, S. E., Antoniou, P. P., Kazantzidou, A., Antonopoulos, D. F., Papageorgiou, I., and Tjamos, E. C. 2004. Aspergillus niger and Aspergillus carbonarius in Corinth raisin and wine-producing vineyards in Greece: population composition, ochratoxin A production and chemical control. J. Phytopathol. 152:250-255.

47. Trotel-Aziz, P., Couderchet, M., Vernet, G., and Aziz, A. 2006. Chitosan stimulates reactions in grapevine leaves and inhibits development of Botrytis cinerea. Eur. J. Plant Pathol. 114:405-413.

48. USDA. 2011. National Organic Program. National list and petitioned substances. http://www.ams.usda.gov/AMSv1.0/nop

49. Van Loon, L. C., and Van Strien, E. A. 1999. The families of pathogenesisrelated proteins, their activities, and comparative analysis of PR-1 type proteins. Physiol. Mol. Plant Pathol. 55:85-97.

50. Xing, R., Yu, H., Liu, S., Zhang, W., Zhang, Q., Li, Z., and Li, P. 2005. Antioxidative activity of differently regioselective chitosan sulfates in vitro. Bioorg. Med. Chem. 13:1387-1392.

51. Yen, M.-T., Yang, J.-H., and Mau, J.-L. 2008. Antioxidant properties of chitosan from crab shells. Carbohydr. Polymers 74:840-844.

52. Yilmaz, Y., and Toledo, R. T. 2004. Major flavonoids in grape seeds and skins: antioxidant capacity of catechin, epicatechin and gallic acid. J. Agric. Food Chem. 52:255-260. 